Çukurova Üniversitesi Mühendislik Mimarlık Fakültesi Dergisi, 31(1), 107-116 ss. , Haziran 2016

Çukurova University Journal of the Faculty of Engineering and Architecture, 31(1), pp. 107-116, June 2016

\title{
Dairesel Temel Altındaki Kum Zeminlerde Donatı Tabakasının Optimum Derinliğinin Belirlenmesi
}

\author{
Baki BAĞRIAÇIK ${ }^{* 1}$ \\ ${ }^{1}$ Çukurova Üniversitesi, Mühendislik Mimarlık Fakültesi, Inşaat Mühendisliği Bölümü, Adana
}

Geliş tarihi: 06.01.2016

Kabul tarihi: 11.05 .2016

\section{Özet}

$\mathrm{Bu}$ çalışmada, dairesel temel altında, donatı ile güçlendirilmiş zeminlerdeki ilk donatı tabakasının optimum derinliği, yükleme ve gerilme açısından deneysel olarak belirlenmiştir. Zemin içerisinde belirlenen derinliklere geogrid donatı yerleştirilerek, meydana gelen ilave düşey gerilme değerleri basınç algılayıcıları yardımıyla ölçülmüsşür. Deneylerde, sabit bir derinlikte kum tabakası hazırlanarak, temelden dolayı oluşan donatılı durumlarda, $\mathrm{Z}=2,0 \mathrm{D}$ derinlikte meydana gelen gerilme değerleri ölçülmüştür. Literatürde mevcut donatısız durumda ölçülmüş gerilme değerleri, bu çalışmada temel tabanından itibaren farklı derinliklere $(\mathrm{U}=0,10 \mathrm{D}, \mathrm{U}=0,15 \mathrm{D}, \mathrm{U}=0,20 \mathrm{D}, \mathrm{U}=0,25 \mathrm{D}, \mathrm{U}=0,30 \mathrm{D}, \mathrm{U}=0,35 \mathrm{D}, \mathrm{U}=0,40 \mathrm{D}, \mathrm{U}=0,45 \mathrm{D}$ ve $\mathrm{U}=0,50 \mathrm{D})(\mathrm{U}=$ geogridin temel tabanından itibaren derinliği, $\mathrm{D}=$ temelin çapı, $\mathrm{Z}=\mathrm{kum}$ tabakası derinliği) yerleştirilen tek sıra geogrid donatı kullanılması durumunda, ölçülen gerilme değerleri ile karşılaştırılmışıtır. Sonuçta, temel tabanından itibaren yaklaşı $\mathrm{U}=0,35 \mathrm{D}$ derinliğe kadar gerilme değerlerinde belirli oranlarda azalmalar meydana gelirken, $\mathrm{U}=0,35 \mathrm{D}$ 'den daha derinlerde kaydadeğer bir ilave gerilme azalması meydana gelmediği görülmüştür. Buna bağlı olarak ilk donatı tabakasının optimum derinliği yaklaşı $\mathrm{U}=0,35 \mathrm{D}$ olarak belirlenmiş̧tir.

Anahtar Kelimeler: Model deney, Donatı tabakası optimum derinliği, İlave düşey gerilme, Basınç algılayıc1, Dairesel temel

\section{Determination the Optimum Depth of Reinforcement Layer under Circular Footing on Sandy Soils}

\begin{abstract}
In this study, additional vertical stresses, which occur in a soil as a result of uniformly loaded circular footing, resting on sandy soils reinforced by geogrids, have been investigated by laboratory model tests. Additional vertical stress values that occur on a horizontal planes of particular specified depths, have been measured with pressure transducers. In all tests, a sandy soil layer has been prepared at fixed depth $(\mathrm{Z}=2,0 \mathrm{D})$. The additional vertical stresses have been measured in the fixed depth, by replacing the

* Yazışmaların yapılacağı yazar: Baki BAĞRIAÇIK, Ç.Ü., Mühendislik Mimarlık Fakültesi, Inşaat Mühendisliği Bölümü, Adana. bbagriacik@cu.edu.tr
\end{abstract}


geogrid's depth. Geogrid, which placed into the depths of $U=0,10 D, U=0,15 D, U=0,20 D, U=0,25 D$, $\mathrm{U}=0,30 \mathrm{D}, \mathrm{U}=0,35 \mathrm{D}, \mathrm{U}=0,40 \mathrm{D}, \mathrm{U}=0,45 \mathrm{D}$ and $\mathrm{U}=0,50 \mathrm{D}(\mathrm{U}=$ depth of geogrid from foundation, $\mathrm{D}=$ radius of footing, $Z=$ depth of sandy soil ) at soil, have been used in the tests. Finally, the geogrid's optimum depth has been determined in terms of stress and loading. According to test results, it has seen that the geogrid's optimum depth is approximately $\mathrm{U}=0,35 \mathrm{D}$.

Keywords: Model tests, Reinforcement layer's optimum depth, Additional soil stress, Stress transducer, Circular footing

\section{GíRiş}

Zeminler, mühendislik bakış açısıyla, homojen ve izotrop olmamakla birlikte, özellikleri çevre koşullarına, jeolojik tarihçesine ve zamana bağlı olarak büyük değişiklikler göstermektedir. Birçok inşaat malzemesi için, tasarım ve uygulama problemlerinin çözümünde genel olarak malzeme davranışının tam olarak kavranması gerekmeden sabit katsayıların kullanılması yeterli olurken, zeminlerin mühendislik davranışlarını tanımlayan sabit malzeme katsayılarının ve genel analitik modellerin belirlenmesi mümkün olamamaktadır. Zemin davranışlarııın, her proje sahası için ayrı ayr1 belirlenmesi ve bu yapilırken de arazide geçerli olacak koşulların dikkatli bir şekilde incelenmesi gerekmektedir. Ayrica, zemin davranışını etkileyen faktörlerin iyi anlaşılmaması, elde edilen sonuçların birçok durumda yanıltıcı olmasına yol açabilmektedir [1]. Bu yüzden, zemin ile ilgili problemlerde, kullanılacak malzeme özelliklerinin hangi koşullarda belirlendiği ve geçerliliğini koruduğunu anlayarak, güvenli ve ekonomik mühendislik çözümleri elde etmek mümkün olabilmektedir [2].

Zeminler, çok karmaşık bir malzeme olmaları nedeni ile zemin içerisinde gerçekçi gerilmedeformasyon analizleri yapmak da oldukça zordur.

$\mathrm{Bu}$ nedenle Elastisite Teorisi kullanılırken şu kabuller yapilır:

* Zemin, elastik olup, gerilme-deformasyon ilişkisi doğrusaldır.

* Zemin ortam homojendir. Diğer bir deyişle, elastik sabitler, elastisite modülü, E ve poisson oranı, $\mu$ her noktada aynıdır.
- Zemin ortamı izotroptur; özellikleri bir noktadan, her yönde aynıdır.

* Zemin ortam yarı sonsuzdur; bir düzlemin altında, her yönde, sonsuz mesafeye uzanır [2].

Elastisite teorisinden yararlanarak elde edilen bu çözümlerde, düşey gerilme dağılımları zeminin malzeme özelliklerinden bağımsızdır. Ayrıca zeminin türü ve sıkılık gibi parametreleri dikkate alınamamakta, her cins zemin için aynı gerilme dağılımları elde edilmektedir [3]. Fakat, zeminler için gerilme analizinde, zemin cinsinin ve onun aktaracağ 1 gerilmelerin çok büyük önemi vardır. $\mathrm{Bu}$ yüzden, zeminlerde ilave yüklerden dolayı oluşan düşey gerilme değerlerinin deneysel yollarla bulunması zorunluluğu ortaya çıkmaktadır.

Son yıllarda hızla artış gösteren dünya nüfusu ve buna paralel olarak artan barınma ihtiyac1, yerleşim alanı gereksiniminin de hızla artmasına neden olmuştur [4].

$\mathrm{Bu}$ durumun yansıması olarak arsa sıkıntısı ve yüksek maliyetler ortaya çıkmış, taşıma gücü ve oturma özellikleri açısından sorunlu zeminlerde yapılaşma ve mevcut yerleşim alanlarının en iyi şekilde değerlendirilmesi zorunlu hale gelmiştir. $\mathrm{Bu}$ durumda, ya derin temel uygulamasina geçilmeli ya da temel zemininde, zemin iyileştirme yöntemi uygulanabilir. Alternatif olması ve özellikle ekonomik olması sebebiyle, zemin iyileştirme yöntemlerinden, donatılı zemin kullanımı sürekli yaygınlaşmaktadır [4].

Zeminlerde donatı ile güçlendirme sağlanırken ise, dikkat edilmesi gereken hususlardan birisi de, 
donatının temel tabanından itibaren hangi derinliğe yerleştirileceğidir.

$\mathrm{Bu}$ çalışmada, donatı ile güçlendirilmiş kumlu zeminler üzerine oturan dairesel bir temelden dolayı zemin içinde oluşan ilave düşey gerilme değerleri laboratuvar model deneyleri yapılarak araştırılmış ve ilk donatı tabakasının optimum derinliği, yükleme ve gerilme açısından belirlenmiştir.

\section{2. ÖNCEKİ ÇALIŞMALAR}

Terzaghi [5], kum ve kil numunelerde düşey yüklerden dolayı oluşan yatay ve düşey gerilmeleri üretmiş olduğu deney düzeneğiyle ölçmüştür. Sonuçta, Donath [6] tarafindan yatay gerilmenin düşey gerilmeye oranı şeklinde tarif edilen sükunetteki yanal zemin basınç katsayısı, $\mathrm{K}_{0}$ değerlerini elde etmiş ve kaba kum için $\mathrm{K}_{0}=0,42$ değerini belirlemiştir [7].

Scheidig ve Kögler [8], bir kum dolgusuna yük uygulayarak, belirli derinliklerde bulunan yatay düzlemlerin çeşitli noktalarında meydana getirdiği basınçları ölçmüşlerdir. Hendron [9], tarafından özel bir ödometre ile oluşturulan deney düzeneğinde, yanal basınçlar, ödometre ringine yapıştırılan ötelenme ölçerlerle ölçülmüştür.

Hanna ve Ghaly, farklı sıkılıklarda kum zeminlerde yatay ve düşey gerilmeleri, basınç algılayıc1 kullanarak ölçmüşlerdir. Ölçülen sonuçlar ile Jaky [10] tarafindan verilen $\mathrm{K}_{0}=1$-sin $\phi$ değerleri ile karşılaştırılarak, sıkılığın artmasına bağli olarak deneysel ve teorik $\mathrm{K}_{0}$ değerlerinin azaldığını belirlemişlerdir. Ayrıca, ölçülen ilave gerilmelerin teorik değerlerden daha büyük değerler olduğu görülmüştür [7].

Hanna ve Soliman-Saad [11], kompaksiyonun gerilme değerlerine etkisini belirleyebilmek amaciyla kumlu zeminlerde yatay ve düşey gerilmeleri ölçmek için basınç algılayıcıları kullanmışlardır. Ölçülen yatay gerilmelerin düşey gerilmelere oranlanmasıyla bulunan $\mathrm{K}_{0}$ değerlerini, $\mathrm{K}_{0}=1$-sin $\phi$ formülü ile karşılaştırmışlardır. Sonuçta, $\phi$ açısı arttıkça 1-sin $\phi$ formülü ile hesaplanan $\mathrm{K}_{0}$ değerlerinin azaldığını, yatay gerilmelerin düşey gerilmelere oranı olarak bulunan $\mathrm{K}_{0}$ değerlerinin ise arttığını belirlemişlerdir [11].

Laman ve arkadaşları [12], kumun sıkılık oranının ve temel genişliğinin gerilme üzerindeki etkilerini belirleyebilmek amaciyla, kumlu zeminlere oturan dairesel temellerden dolayı zemin içinde oluşan düşey ve yatay gerilme değerlerini model deneyler yaparak incelenmişlerdir. Sonuçta, kum numunelerin sıkılık oranının arttırılmasıyla, aynı yükler altında daha büyük gerilme değerlerinin oluştuğu gözlenmiştir. Temel genişliğinin artmasıyla da benzer durumun oluştuğu görülmüştür. Ayrıca, ölçüm derinliğinin artmasıyla temel plakası merkezinin altındaki basıncın da azaldığı ve kum numunenin herhangi bir noktasındaki gerilme değerinin uygulanan yük ile orantılı olarak arttığı görülmüştür [12].

Keskin ve arkadaşları [13], kumlu zeminlere oturan düşey yüklü kare temellerin merkezi altında oluşan ilave düşey gerilme değerlerini deneysel ve sayısal olarak araştırmışlardır. Ayrıca, elde edilen değerler Boussinesq yöntemi sonuçlarıyla karşılaştırılmıştır. Sayısal çalışmada, zemin lineer elastik ve non-lineer elasto-plastik malzeme olarak modellenmiş ve analizlerde kullanılan bu modellerin ilave düşey gerilme değerlerine etkisi araştırılmıştır. Çalışma sonunda deneysel, sayısal ve teorik sonuçlar arasında belli derinliklerde genel bir uyum gözlenmiştir [13].

Bağrıaçık ve Laman [14], temel boyut etkisini araştırabilmek amaciyla, kumlu zeminler üzerine oturan farklı boyutlardaki dairesel temellerden dolayı, zemin içerisinde oluşan ilave düşey gerilme davranışlarını laboratuvar model deneyler ile belirlemişlerdir. Sonuç olarak, kumlu zeminlerde boyut etkisinin önemli mertebelerde olmadı̆̆ını belirtmişlerdir [14].

Bağrıaçık ve Laman [15], temellerin şekil etkisini araştırabilmek amaciyla, kumlu zeminler üzerine oturan farklı geometrilere sahip yüzeysel temellerden dolayı, zemin içinde oluşan ilave düşey gerilme davranışlarını laboratuvar model deneyleri ile belirlemişlerdir. Sonuçta, farklı 
geometrilerdeki temellerde şekil etkisinin önemli mertebelerde olduğu görülmüştür [15].

Bağrıaçık ve Laman [16], donatısız ve donatılı kumlu zeminler üzerine oturan yüzeysel temellerden dolayı zemin içinde oluşan ilave düşey gerilme davranışlarını, laboratuvar model deneyleri yapılarak araştırmıştır. Sonuçta, geogrid donatılı kumlu zeminler üzerine oturan yüzeysel temellerden dolayı zemin içinde oluşan ilave düşey gerilmelerin, donatısız duruma göre, \%27 mertebelerinde fazladan azaldığı görülmüştür [16].

Bağrıaçık ve arkadaşları [17], dairesel temellerden dolayı zemin içinde oluşan ilave düşey gerilme davranışlarını laboratuvar model deneyleri yaparak araştırmışlar ve literatürdeki teorik yöntemlerle karşılaştırmışlardır. Sonuç olarak, Boussinesq çözümünün, deney sonuçları ile uyumlu görülmüştür [17].

Bağrıaçık ve arkadaşları [18], yatay gerilmelerin düşey gerilmelere oranlanmasıyla bulunan $\mathrm{K}_{0}$ değerlerinin, derinlik ve zemin sıkılığı ile değişimini belirleyebilmek amacıyla, kumlu zeminler üzerine oturan dairesel temellerden dolayı zemin içerisinde oluşan ilave yatay ve düşey gerilme değerleri laboratuvar model deneyleri ile belirlemişlerdir. Sonuçta, $\mathrm{K}_{0}$ değerlerinin, derinlik arttıkça azaldığı ve sıkılık arttıkça $\mathrm{K}_{0}$ değerlerinin azaldığ [18].

Bağrıaçık ve arkadaşları [19], donatı ile güçlendirilmiş kare bir temel altındaki zeminlerde optimum ilk donatı tabakası derinliğini, yükleme ve gerilme açısından belirleyebilmek amaciyla laboratuvar model deneyleri gerçekleştirmişlerdir. Sonuçta, kare temel tabanından itibaren, temel genişliğinin 0,40 katı derinliğe kadar gerilme değerlerinde belirli oranlarda azalmalar meydana gelirken, temel genişliğinin 0,40 katından daha derinlerde ilave herhangi bir gerilme azalması meydana gelmediği görülmüştür. Buna bağlı olarak, kare temellerde ilk donatı tabakasının optimum derinliği, kare temel genişliğinin 0,40 katı olarak belirlenmiştir [19].
Örnek ve arkadaşları [20], kumlu zeminlere oturan eksantrik yüklü şerit temellerin davranışlarını belirleyebilmek amaciyla laboratuvar model deneyleri gerçekleştirmişlerdir. Sonuçta, yük eksantirisitesi arttıkça nihai taşıma gücünün azaldığı görülmüştür [20].

Türedi ve Örnek [21], dikdörtgen temelin farklı yükleme koşullarında zemine oturması sonucunda meydana gelen düşey gerilmeleri belirleyebilmek amaciyla model deneyler gerçekleştirmişlerdir. Ayrıca, deney sonuçlarını literatürdeki teorik yöntemlerle (Boussinesq, Westergaard ve 2:1 Yöntemi vb.) karşılaştırmışlardır. Sonuçta, eksantirisite arttıkça taşıma gücü değerlerinin azaldığı, temel merkezinden uzaklaşıldıkça da gerilme değerlerinde azalmalar tespit edilmiş ve model deney sonuçları ile teorik sonuçların da birbirleri ile uyumlu oldukları belirlenmiştir [21].

\section{MATERYAL METOD}

Çalışmalarda, Çakıt nehir yatağından çıkarılan kum numuneler kullanılmıștır. Kum numune, TS 1500 'e göre $0,074 \mathrm{~mm}$ çaplı ve $1 \mathrm{~mm}$ çaplı eleklerden yıkanarak elenmiştir. Çukurova Üniversitesi İnşaat Mühendisliği Bölümü Zemin Mekaniği Laboratuvarında, No. 18 ile No. 200 arasında kalan kumlar, endeks ve kayma mukavemeti özelliklerinin belirlenmesi amacıyla deneyler yapılmıştır [22].

Deneysel çalışmada kullanılan kumun Türk standartlarına göre dane çapı dağılımı elde edilmiştir. Dane çapı dağılım eğrisinden deney kumunun, zemin sınıfi, TS 1500'e göre uniform temiz kum (SP) olarak belirlenmiştir. Elek analizi deney sonuçları Çizelge 1'de verilmiştir.

Deneysel çalışmalar, $50 \mathrm{~cm}$ genişliğinde kare kesitli kasa içerisinde gerçekleştirilmiştir. Deney kasası iskeleti çelik profillerden olup, ön ve arka yüzü cam, yan yüzeyler ile alt taban ise, ahşap malzemeden imal edilmiştir. 
Çizelge 1. Zemin özellikleri [16]

\begin{tabular}{|c|c|c|}
\hline Granülometri Parametreleri & Birim & Değer \\
\hline Orta Kum Yüzdesi & $\%$ & 46,40 \\
\hline İnce Kum Yüzdesi & $\%$ & 53,60 \\
\hline Efektif Dane Çapı, $\mathrm{D}_{10}$ & $\mathrm{~mm}$ & 0,18 \\
\hline $\mathrm{D}_{30}$ & $\mathrm{~mm}$ & 0,30 \\
\hline $\mathrm{D}_{60}$ & $\mathrm{~mm}$ & 0,50 \\
\hline Üniformluk Katsayısı, $\mathrm{C}_{\mathrm{u}}$ & - & 2,78 \\
\hline Derecelenme Katsayısı, $\mathrm{C}_{\mathrm{c}}$ & - & 1,00 \\
\hline Zemin Sınıfı & - & $\mathrm{SP}$ \\
\hline $\begin{array}{c}\text { Maksimum Kuru Birim } \\
\text { Hacim Ağıllık }\end{array}$ & $\mathrm{kN} / \mathrm{m}^{3}$ & 17,06 \\
\hline $\begin{array}{c}\text { Minimum Kuru Birim } \\
\text { Hacim Ağırlık }\end{array}$ & $\mathrm{kN} / \mathrm{m}^{3}$ & 15,03 \\
\hline Dane Birim Hacim Ağılılı & $\mathrm{kN} / \mathrm{m}^{3}$ & 26,80 \\
\hline \multicolumn{2}{|c|}{} \\
\hline
\end{tabular}

Deneysel çalışmada, çapı $9 \mathrm{~cm}$ olan dairesel temel kullanılmıştır.

Farklı yükleme hızlarında çekme ve basınç uygulayabilen özel bir yükleme düzeneği geliştirilerek deneyler gerçekleştirilmiştir.

Temel plakasına gelen yük değerlerini ölçebilmek amacıyla ESIT firması tarafindan üretilen elektronik yük hücresi kullanılmışıtır.

Zeminde meydana gelen gerilmeleri ölçmek için $200 \mathrm{kPa}$ kapasiteli basınç algılayıcılar kullanılmıştır (Şekil 1).

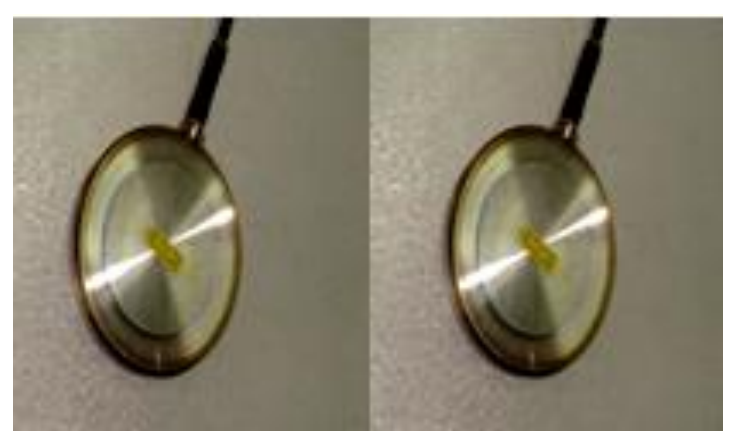

Şekil 1. Basınç algılayıcılar

Kullanılan geogrid donatı, temel tabanından itibaren farklı derinliklere $(\mathrm{U}=0,10 \mathrm{D}, \mathrm{U}=0,15 \mathrm{D}$, $\mathrm{U}=0,20 \mathrm{D}, \quad \mathrm{U}=0,25 \mathrm{D}, \quad \mathrm{U}=0,30 \mathrm{D}, \quad \mathrm{U}=0,35 \mathrm{D}$, $\mathrm{U}=0,40 \mathrm{D}, \mathrm{U}=0,45 \mathrm{D}$ ve $\mathrm{U}=0,50 \mathrm{D})$ Şekil 2 'de görüldüğü gibi yerleştirilerek $\mathrm{Z}=2,0 \mathrm{D}$ derinlikte meydana gelen gerilme değerleri ölçülmüsşür.

Çalışmada, Çizelge 2'de özellikleri bulunan Secugrid markalı geogridler kullanılmıştır.

Çizelge 2. Geogridlerin özellikleri [16]

\begin{tabular}{|c|c|c|}
\hline Teknik Özellikler & Birim & $60 / 60 \mathrm{Q}_{1}$ \\
\hline Malzeme & - & Polipropilen \\
Dayanım. Çekme $\mathrm{md} / \mathrm{cmd}^{*}$ & $\mathrm{kN} / \mathrm{m}$ & $\geq 60 / \geq 60$ \\
\hline $\begin{array}{c}\text { \%2 uzamada çekme } \\
\text { dayanımı, md/cmd }\end{array}$ & $\mathrm{kN} / \mathrm{m}$ & $22 / 22$ \\
\hline $\begin{array}{c}\text { \%5 uzamada çekme } \\
\text { dayanımı, md/cmd }\end{array}$ & $\mathrm{kN} / \mathrm{m}$ & $48 / 48$ \\
\hline $\begin{array}{c}\text { Açılık, md } \times \mathrm{cmd}^{*} \\
\mathrm{~mm} \mathrm{x}\end{array}$ & $\mathrm{mm}$ & $31 \times 31$ \\
\hline $\begin{array}{c}\text { Rulo genişliği / } \\
\text { uzunluğu }\end{array}$ & $\mathrm{m} \mathrm{x} \mathrm{m}$ & $4,75 \times 100$ \\
\hline *md = machine direction, *cmd= cross mach. \\
\hline
\end{tabular}

Geogrid donatının yerleşim düzeni Şekil 3'te gösterilmiştir. 


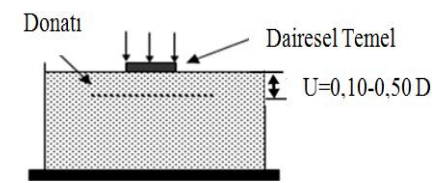

Şekil 2. Donatının yerleştirilmesi [16]

Uygulanan düşey yükler, yük hücresi yardımıyla 8 kanal girişli ADU (Autonomous Acquisition Data Unit) data logger cihazına aktarılmıştır. Bu veriler daha sonra bilgisayar ortamında DIALOG programı yardımıla sayısal değerlere dönüştürülmüştür. Uygulanan düşey yüklerden dolayı meydana gelen düşey gerilmeler ise, basınç algılayıcıları yardımıyle, TML markalı TDS-301 modelindeki taşınabilir data loggerdan elde edilmiştir.

Deney düzeneği Şekil 3'te gösterilmiş ve deneyler aşağıda belirtilen hususlara dikkat edilerek gerçekleştirilmiştir.

- Basınç algılayıcıları deney kasasının içerisine deney esnasında hareket etmeyecek şekilde tabana yapıştırılarak sabitlenmiştir [22].

- Kum zemin, kasa içerisine tabakalar halinde ve birim hacim ağırlığ $1 \quad \gamma_{\mathrm{k}}=15,03 \mathrm{kN} / \mathrm{m}^{3}$ olacak şekilde sıkıştırılarak yerleştirilmiştir. $\mathrm{Bu}$ amaçla, her tabaka için gerekli kum ağırlığı önceden hesaplanarak kontrollü bir şekilde sıkıștırma yapılmıştır.

- Belirlenen tabakaya kadar sıkıştırma işlemi yapılmış, daha sonra geogrid donatı yerleştirilmiş ve sonra da kalan tabakalarda yerleştirilmiştir.

- Sikıştırma işlemi tamamlandıktan sonra zemin yüzeyinin düzgünlüğü su terazisi ile her seferinde kontrol edilmiştir. Daha sonra temel plakası zemin yüzeyine yerleştirilmiştir. $\mathrm{Bu}$ aşamada temel plakasının, basınç algılayıcılarına göre, konumunun uygun yerleştirilmesine dikkat edilmiştir.

- Uygulanan yükün, temel plakası merkezine uniform ve düşey yönde olacak şekilde etki ettirilmesine dikkat edilmiştir.

- Deney sırasında, yükleme hızı her kademede sabit tutularak, kademeli olarak yüklemeye devam edilmiştir.

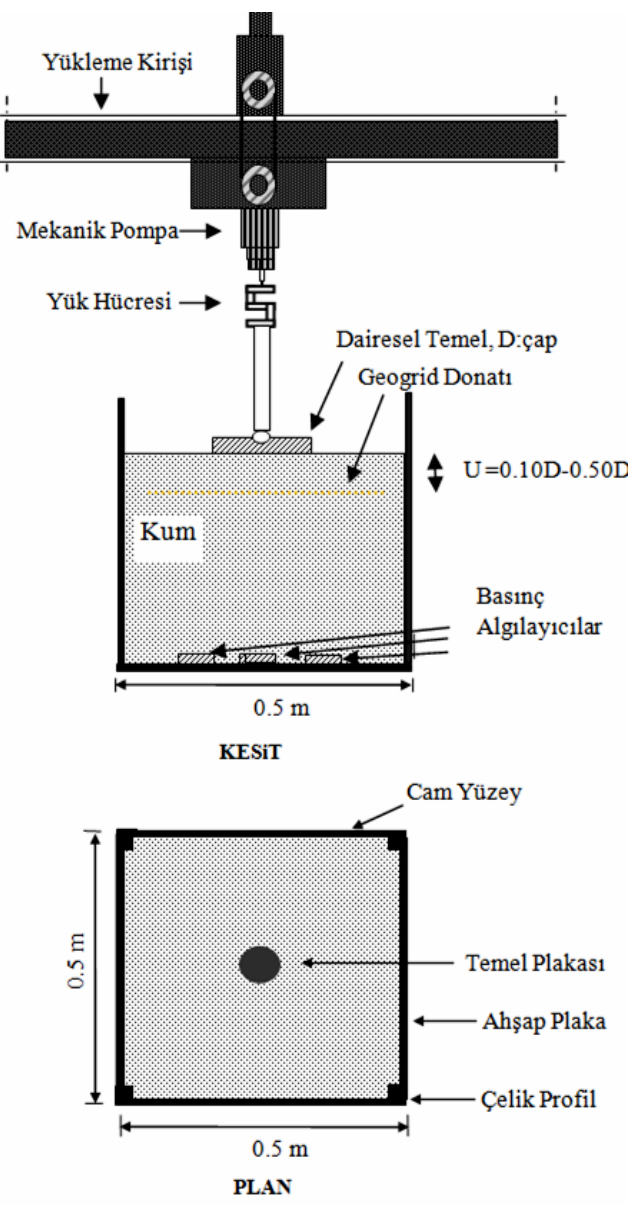

Şekil 3. Deney düzeneği [22]

\section{BULGULAR VE TARTIŞMA}

$\mathrm{Bu}$ çalışmada, donatı kullanılarak sabit bir derinlikte hazırlanan kum tabakasında, temelden dolayı oluşan, $\mathrm{Z}=2,0 \mathrm{D}$ derinlikte meydana gelen gerilme değerleri ile Bağrıç̧ık ve Laman [16] tarafından aynı şartlarda hazırlanan donatısız kumlu zemin durumlarında ölçülen gerilme değerleri karşılaştırılmıştır (U=geogridin temel tabanından itibaren derinliği, $\mathrm{D}=$ temelin çapı, $\mathrm{Z}=$ kum tabakası derinliği, $\mathrm{X}=$ temel merkezinden olan yatay mesafe). Deney sonuçları Şekil 4, 5, 6, $7,8,9,10,11,12,13$ ve 14 'te sunulmuştur. 
Şekil 4, 5, 6, 7, 8, 9, 10, 11, 12'den q=10.22 kPa değerinde uygulanan düşey yüke karşı, $Z=2,0 \mathrm{D}$ 'de, donatilı ve donatisız durumlardaki gerilme değerlerinin değişimleri görülmektedir. Buradan, farklı derinliklere $\mathrm{U}=0,10 \mathrm{D}, \mathrm{U}=0,15 \mathrm{D}, \mathrm{U}=0,20 \mathrm{D}$, $\mathrm{U}=0,25 \mathrm{D}, \quad \mathrm{U}=0,30 \mathrm{D}, \quad \mathrm{U}=0,35 \mathrm{D}, \quad \mathrm{U}=0,40 \mathrm{D}$, $\mathrm{U}=0,45 \mathrm{D}$ ve $\mathrm{U}=0,50 \mathrm{D})$ donatı yerleştirilmesi durumunda, donatisız duruma göre temel merkezinde sırasıyla yaklaşık \%3,7, \%10,0, $\% 18,8 ; \% 31,2 ; \% 37,5 ; \% 50,0 ; \% 50,6 ; \% 51,0$ ve $\% 52,5$ oranlarında ilave gerilme azalmaları meydana geldiği belirlenmiştir. $\mathrm{Bu}$ oranlar, aynı derinlikler için temel merkezinden yatay mesafede uzaklaştıkça da temel merkezindeki oranlarla benzer davranış göstermektedir.

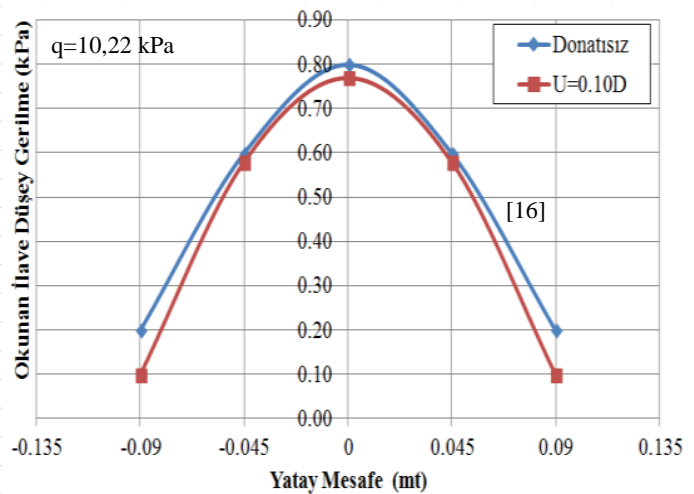

Şekil 4. Donatısız durumdaki gerilme değerlerinin $\mathrm{U}=0,10 \mathrm{D}$ donatı derinliğindeki gerilmelerle karşılaştırılması

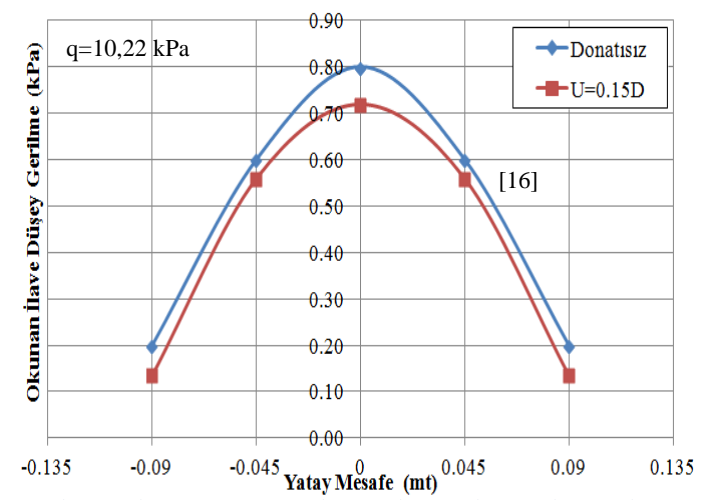

Şekil 5. Donatısız Durumdaki gerilme değerlerinin $\mathrm{U}=0,15 \mathrm{D}$ donatı derinliğindeki gerilmelerle karşılaştırılması

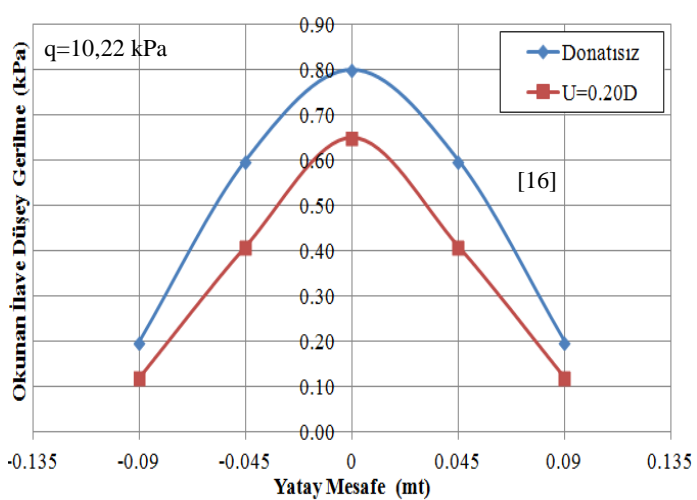

Şekil 6. Donatısız durumdaki gerilme değerlerinin $\mathrm{U}=0,20 \mathrm{D}$ donatı derinliğindeki gerilmelerle karşılaştırılması

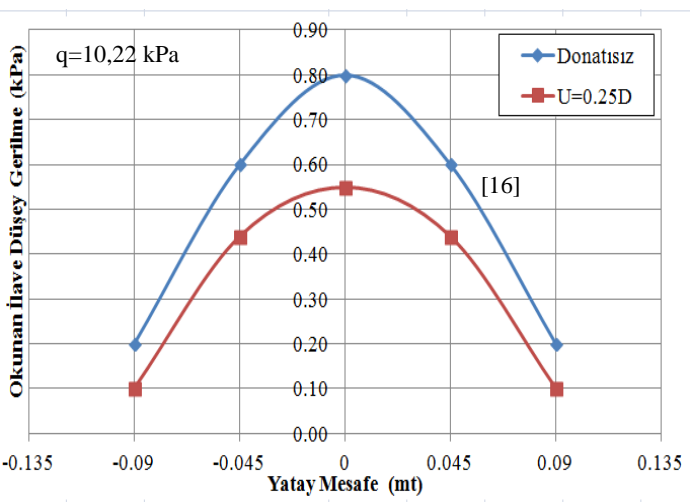

Şekil 7. Donatısız durumdaki gerilme değerlerinin $\mathrm{U}=0,25 \mathrm{D}$ donatı derinliğindeki gerilmelerle karşılaştırılması

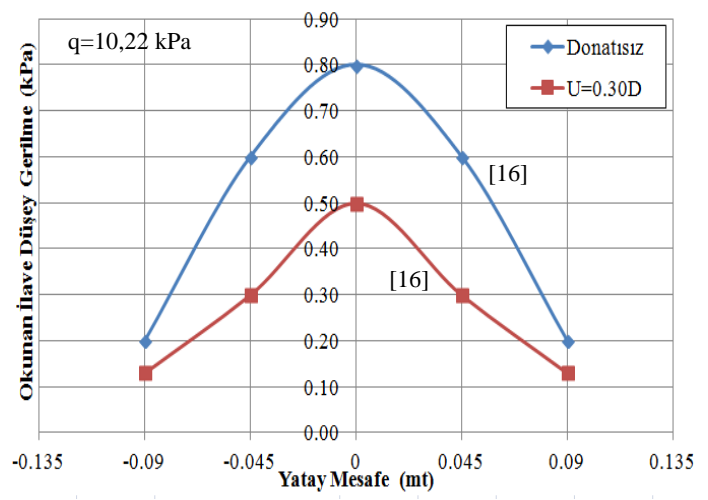

Şekil 8. Donatısız durumdaki gerilme değerlerinin $\mathrm{U}=0,30 \mathrm{D}$ donatı derinliğindeki gerilmelerle karşılaştırılması [16] 


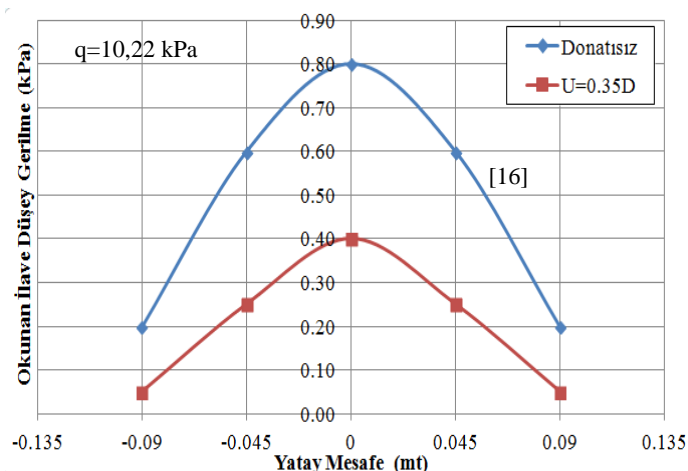

Şekil 9. Donatısız Durumdaki gerilme değerlerinin $\mathrm{U}=0,35 \mathrm{D}$ donatı derinliğindeki gerilmelerle karşılaştırılması

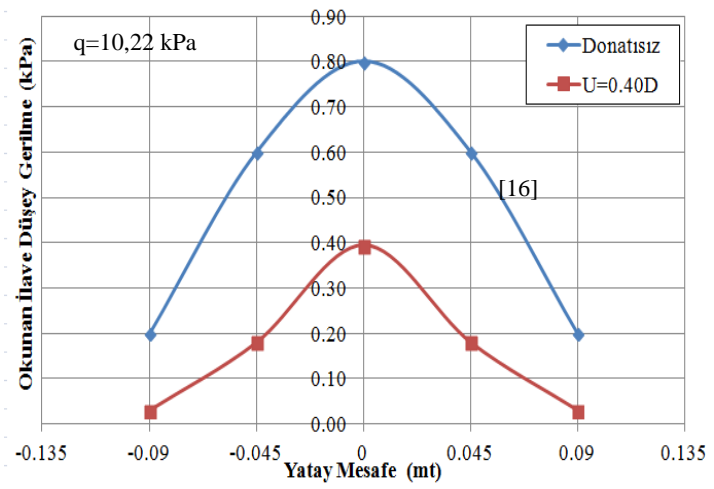

Şekil 10. Donatısız durumdaki gerilme değerlerinin $\mathrm{U}=0,40 \mathrm{D}$ donat1 derinliğindeki gerilmelerle karşılaştırılması

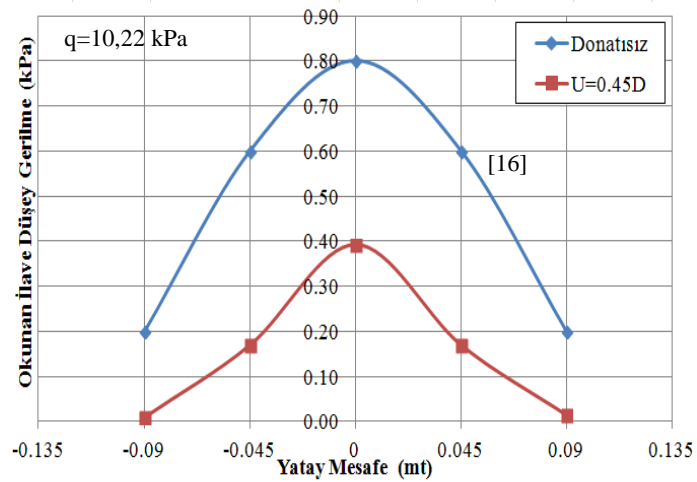

Şekil 11. Donatısız durumdaki gerilme değerlerinin $\mathrm{U}=0,45 \mathrm{D} \quad$ donatı derinliğindeki gerilmelerle karşılaștırılması

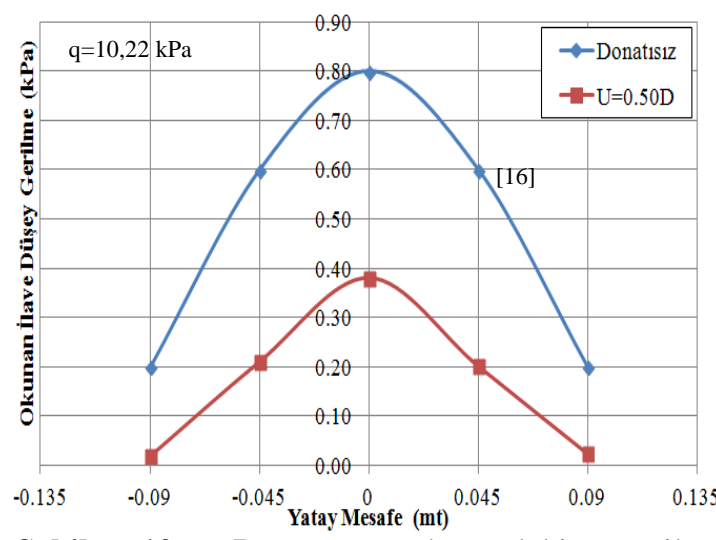

Şekil 12. Donatısız durumdaki gerilme değerlerinin $\mathrm{U}=0,50 \mathrm{D}$ donatı derinliğindeki gerilmelerle karşılaştırılması

Şekil 13'te, farklı donatı derinliklerinde, $\sigma / \mathrm{q}$ değerlerine karşılık X/D oranları görülmektedir. Buradan, temel merkezinden itibaren donat1 derinliği arttıkça, gerilme değerlerinin hem temel merkezinde hem de temel merkezinden yatay mesafede uzaklaştıkça, belirli bir donatı derinliğine kadar azaldığ ise kayda değer bir azalmanın meydana gelmediği belirlenmiştir.

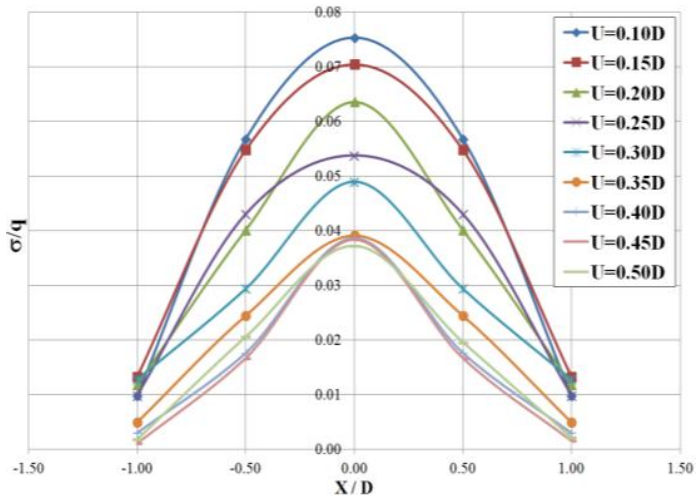

Şekil 13. Farklı donatı derinliğindeki gerilmelerin karşılaştırılması

Şekil 14'te, o/q değerlerine karşılık U/D oranları görülmektedir. Sonuçta, temel merkezinde $\mathrm{U} / \mathrm{D}=0,35$ 'e kadar ölçülen gerilme değerlerinde azalmalar meydana geldiği, $\mathrm{U} / \mathrm{D}=0,35$ 'ten daha derinde bu azalmaların sabit kaldığı görülmüştür. 
Buna bağlı olarak, optimum ilk donatı derinliği $\mathrm{U} / \mathrm{D}=0,35$ olarak belirlenmiştir.

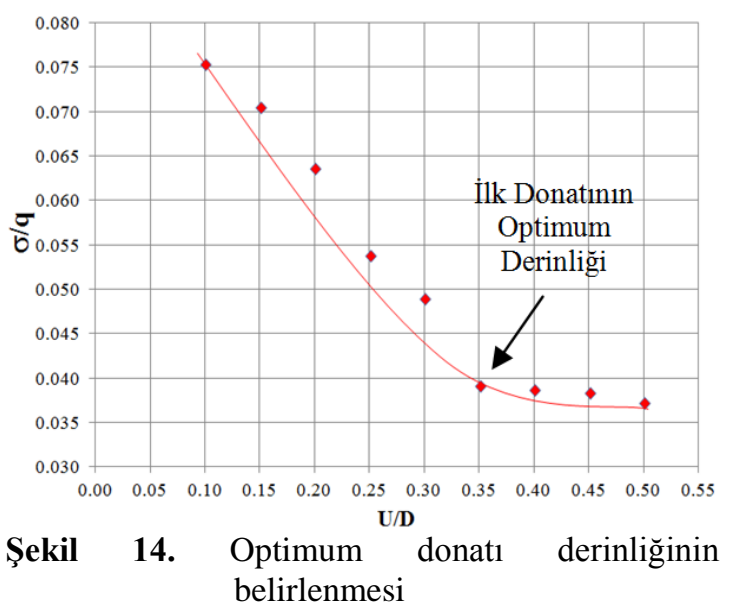

\section{SONUÇLAR}

Uygulanan düşey yük etkisinde, farklı derinliklere donatı yerleştirilmesi durumunda, donatısız duruma göre temel merkezinde sırasıyla yaklaşık $\% 3,7 ; \% 10,0 ; \% 18,8 ; \% 31,2 ; \% 37,5 ; \% 50,0$; $\% 50,6 ; \% 51,0$ ve $\% 52,5$ oranlarında ilave gerilme azalmaları meydana geldiği belirlenmiştir. $\mathrm{Bu}$ oranların, aynı derinlikler için temel merkezinden yatay mesafede uzaklaştıkça da temel merkezindeki oranlarla benzer davranış gösterdiği belirlenmiştir.

Temel merkezinden itibaren donatı derinliği arttıkça, gerilme değerlerinin, belirli bir donatı derinliğine kadar azaldığı $(\mathrm{U} / \mathrm{D}=0,35)$, bu derinlikten itibaren ise kayda değer bir azalmanın meydana gelmediği belirlenmiştir.

Buna bağlı olarak ise optimum ilk donatı derinliği $\mathrm{U} / \mathrm{D}=0,35$ olarak belirlenmiştir (U=geogridin temel tabanından itibaren derinliği, $\mathrm{D}=$ temelin çap1).

\section{KAYNAKLAR}

1. Kumbasar, V., Kip, F., 1984. İnşaat Mühendisliğinde Zemin Mekaniği. Çağlayan Kitabevi, İstanbul, 350s.
2. Uzuner, B.A., 1998. Çözümlü Problemlerle Temel Zemin Mekaniği, Teknik Yayınevi, Ankara.

3. Sağlamer, A., 1972. Kohezyonsuz Zeminlerde Sükunetteki Toprak Basıncı Katsayısının Zemin Parametreleri Cinsinden İfadesi, Doktora Tezi, İstanbul Teknik Üniversitesi, Fen Bilimleri Enstitüsü, İstanbul.

4. Demir, A., 2011. Yumuşak Kil Zemin Üzerinde Güçlendirilmiş Stabilize Dolguya Oturan Yüzeysel Temellerin Analizi, Doktora Tezi, Çukurova Üniversitesi, Adana.

5. Terzaghi, K., 1920. Old Earth Pressure Theories and New Test Results, Engrg. NewsRec., 85 (14), 632-637.

6. Donath, A.D., 1891. Untersuchungen Veber den Erddruck auf Stuetzwaende. Zeitschrift fuer Bauwesen, Berlin, Germany.

7. Hanna, A., and Ghaly, A., 1992. Effects of K0 and Overconsolidation on Uplift Capacity. Journal of Geotechnical Engineering, 118 (9), 1449-1469.

8. Scheidig, Kogler, 1926. Die Verteilung Senkrechter Drücke in Schüttungen, Dissertation, Freiberg.

9. Hendron, A.J., 1963. The Behaviour of Sand in One Dimensional Compression. Ph. D. Thesis, University of Illinios, USA.

10. Jaky, J., 1948. Pressure in Soils. Proc. 2nd Conf. On Soil Mech. and Found. Engrg., A. A. Balkema, Rotterdam, the Netherlands, 1, 103107.

11. Hanna, A.M., Solıman-Saad, N., 2001. Effect of Compaction Duration on the Induced Stress Levels in a Laboratory Prepared Sand Bed. Geotechnical Testing Journal, 24 (4), 430-438.

12. Laman, M., Keskin, M.S., Y1ldı. A.A., 2004. Farklı Sikılıktaki Kumlu Zeminlere Oturan Dairesel Temeller Altında Gerilme Analizi, Türkiye İnşaat Mühendisliği 17. Teknik Kongre ve Sergisi, Yıldız Teknik Üniversitesi, İstanbul.

13. Keskin, M.S., Laman, M., Baran, T., 2008. Kuma Oturan Kare Temeller Altında Oluşan Düşey Gerilmelerin Deneysel Tespiti ve Sayısal Analizi, İMO Teknik Dergi, pp. 45214538, No 299.

14. Bağrıaçık, B., Laman M., 2010. Yüzeysel Temel Geometrisinin Zeminlerde Oluşan 
Gerilmelere Etkisinin Araştırılması. Çukurova Üniversitesi Mühendislik Mimarlık Fakültesi Dergisi, pp. 155-166, No 1-2, Cilt 25.

15. Bağrıaçık, B., Laman M., 2011. Investigation of the Shape Effect at Different Geometries on Stress Distribution of Sandy Soils pp. 78, International Balkans Conference on Challenges of Civil Engineering, BCCCE, 1921 May 2011, EPOKA University, Tirana, ALBANIA.

16. Bağrıaçı, B., Laman M., 2011. Donatısız ve Donatıl1 Kumlu Zeminlere Oturan Dairesel Temeller Altında Gerilmelerin Değişimi. Gazi Üniversitesi Mühendislik Mimarlık Fakültesi Dergisi, Ankara, Vol:26, No:4, 787-800, 2011(SCI).

17. Bağrıaçık, B., Laman M., Demir A., 2011. Kum Zeminlerde Sükunetteki Toprak Basınc1 Katsayısının Deneysel Olarak Belirlenmesi, 4. Geoteknik Sempozyumu, Çukurova Üniversitesi, Adana.

18. Bağrıaçı, B., Laman M., Demir A., 2011. Dairesel Temeller Altında Farklı S1kılıklarda Oluşan Düşey Gerilmelerin Karşılaştırılması, 4. Geoteknik Sempozyumu, Çukurova Üniversitesi, Adana.

19. Bağrıaçı, B., Laman, M., Demir, A., 2012. Kare Temel Altındaki Zeminlerde Optimum Donatı Tabakası Derinliğinin Gerilme Yönünden İncelenmesi, 5. Ulusal Geosentetikler Konferansı, Boğaziçi Üniversitesi, İstanbul.

20. Örnek M., Türedi Y., Dal, K., 2014. Kum Zemine Oturan Eksantrik Yüklü Şerit Temellerin Analizi, Zemin Mekaniği ve Temel Mühendisliği 2. Özel Konulu Sempozyumu, 24-25 Nisan 2014, Antalya.

21. Türedi Y., Örnek M., 2015. Dikdörtgen Temel Altında Gerilme ve Taşıma Gücü Analizi, Çukurova Üniversitesi Mühendislik Mimarlık Fakültesi Dergisi, pp. 1-11, Cilt 30, No 2.

22. Bağrıaçı, B., 2010. Zeminlerdeki Gerilme Durumlarının Deneysel ve Teorik Olarak İncelenmesi, Yüksek Lisans Tezi, Çukurova Üniversitesi, Adana. 